\title{
Recent patent applications in angiogenesis research
}

\begin{tabular}{ll} 
Patent \# & Subject \\
\hline WO 2005116066 & $\begin{array}{l}\text { A new peptide of } 5 \text { to } 40 \text { amino acids from a portion of deco- } \\
\text { rin, which contains leucine-rich repeats (LRRs), or its variant; } \\
\text { useful for treating angiogenesis in cancer, diabetic retinopa- } \\
\text { thy, macular degeneration, rheumatoid arthritis, ulcers, endo- } \\
\text { metriosis and psoriasis. }\end{array}$
\end{tabular}

WO 2005115407 An agent that activates constitutive nitric oxide synthase by inhibitor displacement; useful in the treatment of diseases modulated by nitric oxide synthase activity, e.g., hypertension, angiogenesis, diabetes, emphysema, atherosclerosis and asthma.

US 20050272696 A method of inhibiting or preventing a disease/condition, com prising identifying a disease or condition in a patient, selecting a glycosaminoglycan polymer and providing a composition comprising recombinantly produced defined glycosaminoglycan polymers with a desired specific size distribution. The composition is claimed to inhibit angiogenesis.

US 20050271667 An antibody that specifically binds to an endothelial-derived gene (EG-1) encoded peptide; useful for inhibiting angiogenesis and tumorigenesis.

WO 2005116131 A product comprising hyaluronic acid or its salt, useful for treating, e.g., osteoarthritis, ophthalmological disease and cancer (as an angiogenesis inhibitor).

JP 2005336080 A method for separating and recovering cells for angiogenic treatments by pouring raw material cell sap comprising cells effective for angiogenesis on a trapping filter and recovering the trapped cells.

WO 2005113828 A method of diagnosing cancer, comprising detecting the overexpression of $\mathrm{A} 3$ receptor protein in a sample compared to the level in a healthy mammal. A3 is a receptor antagonist and angiogenesis inhibitor.

WO 2005112569 A method for delivering a therapeutic agent to adventitia of a vessel for the treatment of a vascular condition (e.g., antiinflammatory, angiogenesis inhibitor), involving forming the therapeutic agent into microparticles and dispersing them throughout a liquid carrier to form a therapeutic mixture for delivery by microsyringe.

US 20050267062 A method for treating an ischemic condition or modulating angiogenesis in a subject, comprising introducing a nucleic acid encoding a polypeptide comprising a zinc finger DNAbinding domain and a transcriptional activation domain.

\begin{tabular}{llll} 
Assignee(s) & Inventor(s) & $\begin{array}{l}\text { Priority application } \\
\text { date }\end{array}$ & $\begin{array}{l}\text { Publication } \\
\text { date }\end{array}$ \\
\hline $\begin{array}{l}\text { National University of } \\
\text { Singapore }\end{array}$ & $\begin{array}{l}\text { Ge R, } \\
\text { Kini M }\end{array}$ & $5 / 31 / 2004$ & $12 / 8 / 20005$ \\
& & &
\end{tabular}

Rensselaer Polytechnic Salerno JC, 5/26/2004

$12 / 8 / 2005$

Institute (Troy, NY, USA) Smith SME

(12/8/2005

University of Oklahoma

DeAngelis PL 4/2/1998

$12 / 8 / 2005$

(Norman, OK, USA)

(1)

Regents of the University Nguyen MH
of California (Oakland, CA,

$4 / 15 / 2005$

$12 / 8 / 2005$ USA)

Novozymes Bioploymer

(Bagsværd, Denmark)

Back P,

Thwaites E,

2/15/2005

$12 / 8 / 2005$

Asahi Medical Co. Ltd $\quad$ Hori T,

Hori T,

(Tokyo)

Shiota $Y$

$5 / 26 / 2004$

$12 / 8 / 2005$

King Pharmaceuticals Borea PA,

$5 / 14 / 2004$

$12 / 1 / 2005$

Research \& Development Gessi S,

Leung $E$,

Liboni A,

MacLennan S

$\begin{array}{ll}\text { Medtronic Vascular (Santa } & \text { Cheng } P \text {, } \\ \text { Rosa, CA, USA) } & \text { Judd D, }\end{array}$

Judd D,
Patel K,

Sundar RR,

Tedeschi E,

Tremble P,

Udipi K

Sangamo Biosciences

Eisenberg SP, 12/6/2001

$12 / 1 / 2005$

(Richmond, CA, USA)

Jamieson $A$,

Jarvis $E$,

Liu $\mathrm{P}$,

Liu $Q$,

Rebar E,

Wolffe A

WO 2005113596 New polypeptides, specifically isoforms of cell surface receptors such as EphA, VEGF, MET, RON, CSF, etc.; useful in treating cancer and inflammatory, infectious, angiogenesis-related conditions or immune disorders.

WO 2005110407 The dispersion of nanoparticles comprising a lactam compound, at least one stabilizer and liquid medium; inhibits angiogenesis and useful for treating, e.g., cancer, Alzheimer disease and rheumatoid arthritis.

US 20050261316 New substituted purine-2,6-dione compounds that are adenosine receptor $\mathrm{A}-2 \mathrm{~B}$ inhibitors; useful for treating, e.g., atherosclerosis, angiogenesis, type II diabetes, cancer, asthma, inflammatory gastrointestinal tract disorders and neurological disorders.

Receptor Biologix (S. San Jin P,

(New York), Elan Pharma Haby TA,

Liversidge $\mathrm{E}$

Elzein E, Ibrahim P, Kalla Elzein E,

$7 / 25 / 2005$

$11 / 24 / 2005$

R, Li X, Palle V, Perry

Ibrahim $P$,

T, Varkhedkar V, Xiao D, Kalla R,

Li X,

Palle V,

Perry T,

Varkhedkar V,

Xiao D,

Zablocki J

Source: Thomson Scientific Search Service (formerly Derwent). The status of each application is slightly different from country to country. For further details, contact Thomson Scientific, 1725 Duke Street, Suite 250, Alexandria, Virginia 22314, USA. Tel: 1 (800) DERWENT (http://www.thomson.com/scientific). 